\title{
Feral pigeons in urban environments: dietary flexibility and enzymatic digestion?
}

\author{
Palomas domésticas en ambientes urbanos: ¿flexibilidad dietaria y digestión enzimática?
}

\author{
MARÍA EUGENIA CIMINARI ${ }^{1,2}$, GRACIELA DEL VALLE MOYANO ${ }^{1,2}$, \\ JUAN GABRIEL CHEDIACK ${ }^{1,2}$ \& ENRIQUE CAVIEDES-VIDAL ${ }^{1,2}$ *
}

\author{
${ }^{1}$ Área de Biología, Departamento de Bioquímica y Ciencias Biológicas, Facultad de Química, Bioquímica y Farmacia, \\ Universidad Nacional de San Luis, CC 226, 5700, San Luis, Argentina \\ ${ }^{2}$ Laboratorio de Biología "Prof. Enrique Caviedes Codelia", Facultad de Ciencias Humanas, \\ Universidad Nacional de San Luis, CONICET CC 226, 5700, San Luis, Argentina; \\ *e-mail for correspondence: enrique.caviedes@gmail.com
}

\begin{abstract}
Columba livia, original from Europe, is at present widely distributed all over the world. These granivores colonized urban environments where the availability of crops and seeds is not always permanent and, for that are forced to exploit other resources with different composition, e.g. high protein foodstuff. Thus, feral pigeons should have the ability to survive on a diet rich in protein as they do with starchy items by having an adequate digestive biochemical machinery to process it. Phylogenetical and functional hypothesis has been proposed linking dietary flexibility and enzyme lability. All Passeriformes studied to date show the expected positive correlation between aminopeptidase- $\mathrm{N}$ and dietary protein but not for intestinal carbohydrases. Conversely, all the non-passerine species modulate intestinal carbohydrases, but not peptidases. Moreover, different scenarios may be posed as the output of a phylogenetical effect, e.g., adding constraints to a lability scheme in certain groups or just determining it (e.g., intestinal disaccharidases modulated in Galloanserae and peptidases modulated in Passeriformes). Consequently, we tested the prediction that feral pigeons adjust digestive enzyme activities according to the level of the respective substrate (e.g., carbohydrates, protein) in the diet. Birds were fed for 15 days with two different diets, one with high protein content (low in starch) (HP) and the other rich in starch and low in proteins (HS). Pigeons fed on the HP were able to survive with no other dietary supplement, as predicted. Pancreatic enzymes did not change between diet treatments. Birds fed on HP exhibited the predicted upward modulation of aminopeptidase-N activity, when compared to birds on HS, while intestinal carbohydrases did not show differences between diets. These results give an apparent support to the functional hypothesis, but are not enough to reject that the observed intestinal protease lability has a phylogenetical component, because feral pigeons are closely related to Passeriformes. Finally, feral pigeons have the ability to take full advantage of the energy content from proteins, having enough pancreatic proteases activity and modulating the intestinal aminopeptidase-N. These abilities may allow them to use effectively the nutrients found in the cities surviving even when grains are not available along the year.
\end{abstract}

Key words: feral pigeons, dietary flexibility, digestive plasticity, intestinal enzymes, pancreatic enzymes.

\section{RESUMEN}

La paloma doméstica, originaria de Europa, está distribuida alrededor del mundo. Estas aves granívoras colonizan zonas urbanas donde granos y semillas no están disponibles todo el año, por lo que deben explotar recursos con una composición química diferente, (e.g., ricos en proteínas). Entonces, estas aves debieran poseer la capacidad de sobrevivir con una dieta proteica, utilizando una maquinaria bioquímica digestiva adecuada. Se han propuesto dos hipótesis, una funcional y otra filogenética, para explicar la flexibilidad dietaria y la labilidad de las enzimas intestinales en aves. Los Paseriformes estudiados al momento muestran una correlación positiva entre $\mathrm{N}$-aminopeptidasa y las proteínas de la dieta, aunque esto no es aparente para las carbohidrasas intestinales. Por el contrario, todas las especies no paseriformes estudiadas modulan las carbohidrasas intestinales, pero no las peptidasas. A su vez se pueden representar diferentes escenarios como producto de la filogenia, por ejemplo, agregando limitaciones a patrones de labilidad o directamente determinándolos (e.g., la modulación de las disacaridasas en Galloanserae y la modulación de las peptidasas en Paseriformes. Por esto, sometimos a prueba que las palomas ajustan la actividad de las enzimas digestivas de acuerdo al nivel de su respectivo sustrato (carbohidratos o proteínas) en la dieta. Dos grupos de palomas fueron alimentadas 15 días con dietas diferentes, una rica en proteínas y pobre en almidón (HP) y otra rica en almidón y pobre en proteínas (HS). Las palomas alimentadas con HP sobrevivieron sin suplementos dietarios 
adicionales. Las enzimas pancreáticas fueron iguales entre tratamientos. Las palomas alimentadas con HP exhibieron una actividad de $\mathrm{N}$-aminopeptidasa mayor que la de HS, mientras que las carbohidrasas fueron iguales entre dietas. Estos resultados dan soporte a la hipótesis funcional, pero también son insuficientes para rechazar que la labilidad de la proteasa intestinal constituye un efecto filogenético, ya que estas aves constituyen un grupo cercano a los Passeriformes. En síntesis, las palomas poseen la capacidad de utilizar las proteínas debido a que poseen una actividad proteásica pancreática adecuada y modulan la N-aminopeptidasa. Estas características permiten que las palomas domésticas aprovechen efectivamente alimentos que ofrecen las ciudades y sobrevivan aun cuando la disponibilidad de granos sea escasa.

Palabras clave: palomas domésticas, flexibilidad dietaria, plasticidad digestiva, enzimas intestinales, enzimas pancreáticas.

\section{INTRODUCTION}

Columba livia, originally from Europe, is at present widely distributed all over the world. During the eighteenth and nineteenth centuries, feral pigeons were spread intentionally and/or accidentally by travelers (Johnston \& Janiga 1995). These birds colonized urban environments (e.g., cities, towns, docks and others human developments), although some of them settled in the field. In certain city areas, they achieve high densities, sometimes reaching levels that create difficulties for urban life. Their success colonizing metropolitan areas have been explained by lack or low predation and/or competence, availability of nesting places and food in winter (Jokimaki \& Suhonen 1998, Sol et al. 1998).

Feral pigeons are primary granivores, thus when grains or seeds (e.g., crop fields) are available around cities, they use them intensively by flying out of the cities during the day for foraging and coming back for sleeping (Johnston \& Janiga 1995). In these areas, birds may reach very high densities. An interesting issue is that the quality of food and its availability in the field is not constant all year round, so even having cultivated fields in the vicinities, seeds and grains availability may vary seasonally. Consequently, feral pigeons need to ingest other food items. There are authors that consider feral pigeons not as strict granivores but as granivores/omnivores since they include in their diets small invertebrates, insects and high protein substances present in the garbage (Jokimaki \& Suhonen 1998, Lefebvre \& Giraldeau 1984). Thus, these birds should have the ability to digest such foodstuff to use its built-in energy for maintenance during periods where most preferable food items (i.e., seeds, grains) are unavailable. The extent of digestive flexibility in birds is ecologically important for what it permits them do and for how it constrains their feeding ecology or other features of their biology (Caviedes-Vidal et al. 2000).

Therefore, our first goal in this study was to learn if feral pigeons have the capacity to survive on a diet rich in protein as they do with starchy items. To test this, we fed two groups of birds with different diets: one with high content in starch and low in proteins, as it would be when they feed on grains and seeds, and the other with high protein content and low in starch, mimicking a diet rich on arthropods and insects (see Bell 1990).

Chemical breakdown of the food by enzymes of the gastrointestinal tract is an essential trait that relates to the capacity of vertebrates to extract nutrients from its food (Karasov \& Hume 1997). Enzymatic digestion capacity needs to match the diet switch by: (a) having a fixed high constitutive level of the pancreatic and intestinal enzyme pool needed for to breakdown all foodstuffs or, (b) changing the level of enzymes activity in a positive relationship with the substrate that is being digested. Consequently, our second goal was to assess how pancreatic and intestinal enzymes of feral pigeons adequate to digest carbohydrates and proteins fed either on a high starch or a high protein diet. To achieve this goal, we measured the activity of some pancreatic and intestinal enzymes. We assayed amylase (EC 3.2.1.1), the most important carbohydrase secreted by the pancreas (hydrolyses $\alpha-1,4$ glucosidic bonds in large oligosaccharides producing maltose and small oligosaccharides) (Gray 1992). The disaccharides and oligosaccharides formed by the amylase or directly ingested are hydrolysed to monosaccharides by enzymes located in the brush border of intestinal cells. We determined the activity of two disaccharidases, maltase (EC 3.2.1.20) and sucrase (EC 3.2.1.48). Maltase 
activity, resulting from the activity of two enzymes, maltase-glucoamylase and sucraseisomaltase is probably the single best estimator of the ability to assimilate complex soluble carbohydrates (Noren et al. 1986). Sucraseisomaltase is a relatively unspecific enzyme that hydrolyses sucrose, isomaltose and maltose (Hunziker et al. 1986). We also measured trypsin (EC 3.4.4.4) and chymotrypsin (EC 3.4.4.5), since they are important pancreatic proteases. Trypsin hydrolyses peptide bonds that are adjacent to a basic amino acid, whereas chymotrypsin hydrolyses bonds that are adjacent to an aromatic amino acid (Brannon 1990). Oligopeptides are then hydrolysed by a large variety of peptidases in the brush-border membrane. We chose to measure the activity of aminopeptidase-N (EC 3.4.11.2), also known as leucine-aminopeptidase and aminooligopeptidase (Vonk \& Western 1984), a dipeptidase with broad specificity that appears to account for almost all peptidase activity in the brush border membrane (Maroux et al. 1973).

Dietary modulation of digestive enzymes has been studied in several vertebrates, including birds. Several patterns had been apparent from modulation studies. Passerine species do not change their disaccharidase activities in relation to dietary switch (Afik et al. 1995, Martínez del Río 1995, Sabat et al. 1998, Caviedes-Vidal et al. 2000) with the only exception of pine warblers (Levey et al.1999). In contrast, all passerine birds modulate intestinal peptidases (Afik et al. 1995, Martínez del Río 1995, Sabat et al. 1998, Levey et al. 1999, Caviedes-Vidal et al. 2000). Galliforms (i.e., chicks: Siddons 1972, Biviano 1993, Ciminari et al. unpublished results; turkeys: Sell et al. 1988) and Anseriforms (i.e., Canada and snow geese: Ciminari et al. $1999^{1}$, Ciminari et al. 1998) ${ }^{2}$ adjust their disaccharidase activities matching substrate load. Conversely, aminopeptidase-N activity did not show variation in chicken and geese (Ciminari 1997, Ciminari et al. unpublished results) and we are not aware of any

\footnotetext{
${ }^{1}$ CIMINARI ME, C CODORNIÚ, E CAVIEDES-VIDAL, S MC WILLIAMS \& WH KARASOV (1999) Dietary modulation of intestinal carbohydrases in the Arctic geese (Chen caerulescens) of North America. Biocell 23: 11.

2 CIMINARI ME, E CAVIEDES-VIDAL, S MC WILLIAMS \& WH KARASOV (1998) Dietary modulation of the intestinal disaccharidases maltase and sucrase in the Canada geese (Branta canadensis). Biocell 22: 16.
}

study on turkey intestinal peptidases. In relation to the pancreatic enzymes, there are only a few studies on modulation of amylase and peptidases in birds. Chicken modify amylase and peptidase activities following dietary changes (Imondi \& Bird 1967, Hulan \& Bird 1972). In passerines, no changes have been apparent (Caviedes-Vidal \& Karasov. $1995^{3}$, Ciminari et al. 2001) with the exception of pine warbler (Levey et al. 1999).

One interesting question is whether the differences in enzyme modulation observed reflect a dietary pattern, a phylogenetic pattern, or chance. Under the optimality theory and, using economical arguments it has been predicted that phenotypic plasticity would be favored by natural selection (Sibly 1981). Thus, birds feeding on different substrate on a temporal base would exhibit a link between enzyme activity and its specific substrate (Caviedes-Vidal et al 2000, Martínez del Río et al. 1995), i.e., omnivore birds should exhibit more plasticity than specialists. Though, none of the passerines show the expected positive correlation between intestinal carbohydrases and dietary carbohydrate, they all show the expected positive correlation between aminopeptidase- $\mathrm{N}$ and dietary protein. In contrast all the nonpasserine species studied to date show up the expected correlation for the intestinal carbohydrases but not for peptidase (CaviedesVidal et al. 2000). Another determinant of the digestive plasticity may be phylogeny. Different scenarios may be posed as the output of a phylogenetical effect, e.g. adding constraints to a lability scheme in certain groups or just determining it completely, e.g., intestinal disaccharidases modulated in Galliformes and Anseriformes and peptidases modulated in Passeriformes. In this context, it has been proposed an additional hypothesis linking functionally digestive lability of the intestinal enzyme activity to phylogenetical features such as the presence or absence of a functional cecum (Caviedes-Vidal et al. 2000). To date, all birds lacking cecum (e.g., Passeriformes) modulate intestinal peptidase and in contrast, cecal digesters have a fix level of this enzyme, e.g., Canada geese (Ciminari 1997), chicken (Ciminari et al. unpublished results), common quail (Ciminari et al. unpublished results). Within this

\footnotetext{
3 CAVIEDES-VIDAL E \& WH KARASOV (1995) Influences of diet composition on pancreatic enzyme activities in house sparrows. American Zoologist 35: 78A.
} 
framework, feral pigeons may be considered an important inclusion and a good study subject for several reasons: their food habits (i.e., pigeons from the urban sites are omnivores), morphology of the digestive system (i.e., they have a vestigial cecum, Mc Lelland 1989) and phylogeny (i.e., pigeons belong to the Order Columbiformes, Superorder Passerimorphae, closely related to passerines, Sibley \& Ahlquist 1990).

Therefore, our predictions to test in this study are that feral pigeons: (1) may live on a high protein diet as they do with a high carbohydrate diet, (2) modulate peptidase activity in a positive correlation with dietary protein level, (3) do not modulate neither intestinal carbohydrases nor pancreatic enzymes. Lastly, we consider that this study of digestive enzymes in feral pigeons is relevant since (a) it may help us to understand their success in urban colonizing and, (b) it relates to the problem of digestive lability in birds. We are aware that by itself is not going to give a definitive answer, especially in relation to the phylogenetical aspect, because this will require a large multi-species comparison using the comparative method (Harvey \& Pagel 1991, Garland 1992) but it will contribute to broaden the range of species explored.

\section{MATERIAL AND METHODS}

\section{Animal care and housing}

Sixteen adult feral Pigeons (Columba livia) were captured with a live trap near the Universidad Nacional de San Luis Campus (San Luis, Argentina). The birds were housed individually in cages $(0.50 \times 0.30 \times 0.35 \mathrm{~m})$ indoors under relatively constant environmental conditions $\left(25.2 \pm 0.3{ }^{\circ} \mathrm{C}\right.$, relative humidity of $50 \pm 9 \%$ ) on a photoperiod of 14:10 h (light: dark) with ad libitum water and food (Parrillero Iniciador, Ganave, Alimentos Pilar S.A.). Animals were acclimated to laboratory conditions for two weeks prior to use in experiments. Animal care and trial protocols followed Universidad Nacional de San Luis.

\section{Diet acclimation}

After the adjustment period, pigeons were divided randomly in two groups and fed with different semi-synthetic diets: a high protein diet (HP) and a high starch diet (HS) (Caviedes-Vidal et al 2000). Food and water were offered ad libitum for 15 days. To test our first goal we monitored the body mass and observed carefully the behaviour and external condition of a subset of both dietary groups (four individuals of each group, HP and HS).

\section{Sample collection}

The birds were anesthetized using ethyl ether, the abdominal cavity was opened and the entire gastrointestinal tract was removed and chilled in ice-cold avian saline (Caviedes-Vidal \& Karasov 1996). Stomach was removed, cleaned of extraneous tissue and weighed. Pancreas was carefully excised, cleaned of extraneous tissue, divided longitudinally into two parts, placed in tared cryovials, weighed and immediately frozen in a $-140{ }^{\circ} \mathrm{C}$ freezer. The content of the small intestine (SI) was removed, and the SI was measured for length and weighed. Ten-cm length segments of the proximal, medial and most distal intestine (proximal $=$ near to pyloric sphincter) were sectioned for the enzyme assays. Pieces were placed in tared cryovials, weighed and rapidly stored in a $-140{ }^{\circ} \mathrm{C}$ freezer.

\section{Sample preparation}

Intestinal segments were thawed at $4{ }^{\circ} \mathrm{C}$ and homogenized for $30 \mathrm{~s}$ using a Fisher Scientific homogenizer (setting high) in $350 \mathrm{mM}$ mannitol in $1 \mathrm{mM}$ Hepes/KOH buffer $(\mathrm{pH} 7)$, using 10 $\mathrm{mL}$ per $\mathrm{g}$ tissue. We measured activity of membrane-bound enzymes in whole tissue homogenates rather than in mucosal samples or isolated brush border membrane preparations to avoid underestimation of activity as previously reported (Martínez del Río 1990). One part of the pancreas tissue was used for amylase assays. The tissue was thawed at $4{ }^{\circ} \mathrm{C}$ and homogenized for $30 \mathrm{~s}$ using a Fisher Scientific homogenizer (setting: high) in homogenizing buffer Tris buffer ( $\mathrm{pH}$ 8.2) containing $3 \mathrm{mM}$ sodium taurocholate acid, $0.2 \%$ (w/v) Triton X-100, 1 $\mathrm{mM}$ benzamidine and $2 \mathrm{mM}$ hydrocinnaminic acid) using $10 \mathrm{~mL} \mathrm{~g}^{-1}$ tissue. The other pancreas tissue portion was treated identically than for amylase except that both protease inhibitors (hydrocinnaminic acid and benzamidine) were omitted in the homogenizing buffer. 


\section{Pancreatic enzymes}

Analysis of trypsin and chymotrypsin requires prior activation of the zymogens. Trypsinogen was activated to trypsin by using bovine intestine enterokinase ( $\geq 0.5$ units per $\mathrm{mg}$ solid). In preliminary studies we observed that activation for $30 \mathrm{~min}$ at $25^{\circ} \mathrm{C}$ with $5 \mathrm{U} \mathrm{mL}^{-1}$ of enterokinase in $40 \mathrm{mM}$ succinate buffer ( $\mathrm{pH}$ 5.6) was sufficient to completely activate avian trypsinogen. After 30 min, the activation was stopped by the addition of 1.0 volume of $40 \mathrm{mM} \mathrm{HCl}$ containing $5 \mathrm{mM}$ $\mathrm{CaCl}_{2}$ and placement on ice. Chymotrypsinogen was converted to chymotrypsin in the presence of bovine pancreatic TPCK trypsin $\left(11,700 \mathrm{U} \mathrm{mg}^{-1}\right)$. We observed that activation for $40 \mathrm{~min}$ at $25^{\circ} \mathrm{C}$ with $15 \mu \mathrm{g} \mathrm{mL}^{-1}$ in $40 \mathrm{mM}$ succinate buffer $(\mathrm{pH}$ 5.6) was sufficient to completely activate avian chymotrypsinogen. Samples were centrifuged at $20,000 \mathrm{X} \mathrm{g}$ for $15 \mathrm{~min}$ at $4{ }^{\circ} \mathrm{C}$. After $40 \mathrm{~min}$ activation was stopped by addition of 1.0 volume of $40 \mathrm{mM} \mathrm{HCl}$ containing $5 \mathrm{mM} \mathrm{CaCl}_{2}$ and placement on ice.

\section{Trypsin assay}

We determined the activity of trypsin based on the method of Erlanger et al. (1961). Aliquots of $16 \mu \mathrm{L}$, from the homogenate appropriately diluted, were incubated with $800 \mu \mathrm{L}$ of $2 \mathrm{mM}$ DL-BAPNA (benzoyl-arginine-p-nitroanilide) at $\mathrm{pH} 9$ during $10 \mathrm{~min}$ at $40{ }^{\circ} \mathrm{C}$. The reaction was terminated by adding $160 \mu \mathrm{L}$ of $30 \%$ acetic acid. Absorbance at $410 \mathrm{~nm}$ was read and using a p-nitroanilide standard curve it was estimated the amount of p-nitroanilide liberated. All absorbances were read using a Spectronic 21D (Milton Roy, USA) spectrophotometer

\section{Chymotrypsin assay}

The activity of chymotrypsin was also measured by the amount of p-nitroanilide released by the hydrolysis of GPNA (N-glutaryl-L-phenylalaninep-nitroaniline) $1 \mathrm{mM}$ solution at $\mathrm{pH} 7.4$ and $40{ }^{\circ} \mathrm{C}$. The reaction was terminated by adding $160 \mu \mathrm{L}$ of $30 \%$ acetic acid and the absorbance was read at $410 \mathrm{~nm}$ (Erlanger et al. 1966).

\section{Amylase assay}

The activity of amylase was measured by a modification of the 3,5-dinitrosalicylate method (Dahlqvist 1962). Aliquots of $100 \mu \mathrm{L}$ from the homogenate appropriately diluted were incubated with $2 \%$ potato soluble starch ACS reagent at $40{ }^{\circ} \mathrm{C}$ for $3 \mathrm{~min}$. The reaction was terminated by the addition of $1 \mathrm{~mL}$ dinitrosalicylate reagent. The tubes were immersed in boiling water during $10 \mathrm{~min}$. The absorbance was read at $530 \mathrm{~nm}$.

\section{Disaccharidase assays}

We determined the activity of the disaccharidases maltase and sucrase in the intestinal homogenate. We used the colorimetric method developed by Dahlqvist (1984) and modified by Martínez del Río (1990). Aliquots of $40 \mu \mathrm{L}$ of tissue homogenate, appropriately diluted, were incubated with $40 \mu \mathrm{L}$ of $56 \mathrm{mM}$ sugar (maltose and sucrose) solutions in $0.1 \mathrm{M}$ maleate $/ \mathrm{NaOH}$ $\mathrm{pH}$ 6.5. After $10 \mathrm{~min}$ incubation at $40{ }^{\circ} \mathrm{C}$ we arrested the reaction adding $1 \mathrm{~mL}$ of Glicemia Enzimática reagent (Wiener Laboratorios SAIC, Rosario, Argentina). Sample solutions were allowed to stand for $20 \mathrm{~min}$ and then the absorbances were measured at $505 \mathrm{~nm}$ al room temperature. Enzyme activity was determined using a glucose standard curve.

\section{Aminopeptidase- $N$ assay}

We assayed aminopeptidase- $\mathrm{N}$ using L-alanine$p$-nitroanilide as a substrate (Maroux et al 1973). We started the reaction adding aliquots of $10 \mu \mathrm{l}$ of the tissue homogenate to $1 \mathrm{ml}$ assay solution, made of $2.0 \mathrm{mM} \mathrm{L}$-alanine- $p$ nitroanilide in $0.2 \mathrm{M}$ phosphate buffer $\left(\mathrm{NaH}_{2} \mathrm{PO}_{4} / \mathrm{Na}_{2} \mathrm{HPO}_{4}, \mathrm{pH} 7\right)$. The reaction was incubated during $10 \mathrm{~min}$ at $40{ }^{\circ} \mathrm{C}$ and then arrested with $3 \mathrm{ml}$ of chilled $2 \mathrm{M}$ acetic acid. The absorbance was measured at $384 \mathrm{~nm}$, and activity was determined using a $p$-nitroanilide standard curve.

\section{Protein measurement}

The protein concentration of the samples was estimated using the commercial Wiener Lab Proti 2 Assay Kit (EDTA/Cu Reagent, from Wiener Laboratorios SAIC, Rosario). Absorbances were read at $540 \mathrm{~nm}$ and the serum standard provided with the kit was used as standard. 
Standardization of enzyme activities and calculation of summed hydrolysis activity

Total (summed) and standardized intestinal activities were calculated for all enzymes. Activities are presented as total hydrolytic activity $\left(\mu \mathrm{mol} \mathrm{min}^{-1}\right)$, activity per unit intestinal (or pancreas) wet mass $\left(\mu \mathrm{mol} \mathrm{min}^{-1} \mathrm{~g}\right.$ wet tissue $e^{-1}$, and activity per $g$ of protein $\left(\mu \mathrm{mol} \mathrm{m^{-1 }} \mathrm{g}^{\mathrm{g}}\right.$ protein $\left.{ }^{-1}\right)$. The advantages of our normalization procedures are discussed by Martinez del Río (1990). We calculated the summed hydrolysis activity of the pancreas, by multiplying the activity per gram tissue by the pancreas mass, and the summed hydrolysis activity of the entire small intestine by multiplying activity per gram tissue in each region by $1 / 3$ of the small intestine total mass, and summed over the three regions.

\section{Effect of pH and kinetics: pancreatic enzymes}

In order to compare maximal activities, we assessed the effect of $\mathrm{pH}$ on the activity of amylase, trypsin and chymotrypsin in the pancreas. Thus, the selected $\mathrm{pHs}$ for measuring the activities were the optimum for each enzyme. (chymotrypsin 7.4, trypsin 9 and amylase 5.5). In addition, we measured the substrate concentration effect on enzyme activities. Trypsin and chymotrypsin hydrolysis rates exhibited saturable kinetics that was adequately described by the Michaelis-Menten function. Consequently, all the enzyme activities were assayed at a substrate concentration that provides $\mathrm{V}_{\max }$.

\section{Effect of pH and kinetics: intestinal enzymes}

The chosen $\mathrm{pHs}$ for assaying the activities were the optimum we measured for each enzyme ( 7 for aminopeptidase-N, 6 for sucrase and 6.5 for maltase. These $\mathrm{pH}^{*}{ }_{\text {optima }}$ are the same or almost for most of other bird studies (Afik et al. 1995, Sabat et al. 1998, Caviedes-Vidal et al. 2000).

The apparent binding constants $\mathrm{K}^{*}{ }_{\mathrm{m}}$ and $\mathrm{V}_{\text {max }}$ were determined at a substrate concentration varying from 1 to $100 \mathrm{mM}$ for disaccharidases and from 1 to $20 \mathrm{mM}$ for aminopeptidase-N. Aminopeptidase-N, sucrase and maltase exhibited saturable kinetics that was adequately described by Michaelis-Menten functions. The coefficients of correlation $\left(\mathrm{r}^{2}\right)$ for the individual birds tested ranged from 0.967 to 0.999 . Diets did not affect the values of $\mathrm{K}^{*}{ }_{\mathrm{m}}$ in aminopeptidase- $\mathrm{N}\left(\mathrm{F}_{1,6}=\right.$
2.896; $\mathrm{P}=0.140)$, sucrase $\left(\mathrm{F}_{1,6}=1.078 ; \mathrm{P}=\right.$ $0.338)$ and maltase $\left(\mathrm{F}_{1,6}=0.0085 ; \mathrm{P}=0.929\right)$. Aminopeptidase- $\mathrm{N} \mathrm{K}{ }_{\mathrm{m}}$ averaged $1.648 \pm 0.219$, sucrase $\mathrm{K}^{*}{ }_{\mathrm{m}}$ averaged $4.456 \pm 0.297$ and maltase $\mathrm{K}^{*}{ }_{\mathrm{m}}$ averaged $6.128 \pm 0.772$.

\section{Data analysis}

Results are given as means \pm 1 SE, $n$ is number of individuals. Standard least-squares methods were used to estimate parameters of linear regression. One-way analysis of variance (ANOVA) was used to compare the pancreatic enzymes activities among diets. Repeated measures analysis of variance (RM-ANOVA) was used to examine the effect of diet and intestinal region on enzyme activities. The significance level was set at $\mathrm{P}<$ 0.05 . Kinetic parameters were determined by fitting the kinetic data by non-linear curve fitting (gauss Newton routine, SYSTAT, Wilkinson 1992) to the equation relative activity $=\left(V_{\max } \mathrm{X}\right.$ concentration $) /\left(\mathrm{K}_{\mathrm{m}}^{*}+\right.$ concentration $)$.

\section{RESULTS}

\section{Acclimation to the treatment diets}

Birds averaged a 3.2 to $13.6 \%$ decrease of their initial body mass after 15 days of trial under both treatment diets (high protein and high starch) (Table 1), although this change was not significant among diets $\left(\mathrm{F}_{1,14}=2.51, \mathrm{P}=0.135\right)$. We also did not observe any variation of the behavior or the external appearance of the birds. This observation suggests that, as we predicted, pigeons feed on foodstuff made of high protein content and low in carbohydrates with no apparent harm.

\section{Gut morphometrics}

The mass and length of the small intestine and the pancreas mass did not vary between the two dietary groups (Table 1) suggesting that no adequacy of the gut morphology undergoes with the different diets.

\section{Specific and summed activity}

The three pancreatic enzymes assayed were no significantly affected by the treatment diets (amylase: $\mathrm{F}_{1,14}=0.804, \mathrm{P}=0.385$; chymotrypsin: $\mathrm{F}_{1,13}=3.22, \mathrm{P}=0.096$; trypsin: $\mathrm{F}_{1,12}=1.115, \mathrm{P}=$ 
0.312; Fig. 1A, 1B, and 1C) on a tissue specific activity base (per gram wet tissue), neither if expressed on a protein specific base (data not shown). As for the specific activity, summed hydrolysis activity of the whole pancreas did also not differ significantly between diets for amylase, $\left(\mathrm{F}_{1,14}=0.923, \mathrm{P}=0.353\right)$ chymotrypsin $\left(\mathrm{F}_{1,13}=\right.$
$0.135, \mathrm{P}=0.719)$ and trypsin $\left(\mathrm{F}_{1,13}=0.562, \mathrm{P}=\right.$ 0.467) (Fig. 1D, 1E, and 1F). Pancreas protein content did not vary between diets in the birds $\left(\mathrm{F}_{1,14}=4.331, \mathrm{P}=0.056\right)$ and averaged $0.161 \pm$ $0.008 \mathrm{~g}$ protein per gram pancreas. Pancreatic protein content was significantly correlated with pancreatic mass $\left(\mathrm{F}_{1,14}=49.68, \mathrm{P}<0.001\right)$.

TABLE 1

Final body mass and SI and pancreas measures of feral pigeons fed on either a diet rich in protein (HP) or rich in starch (HS)

Masa corporal final y medidas del intestino delgado y páncreas de las palomas domésticas alimentadas con una dieta rica en proteínas (HP) y una rica en almidón (HS)

\begin{tabular}{lcccccc}
\hline Diet & $\mathrm{n}$ & Final Mb $(\mathrm{g})$ & Change in $\mathrm{Mb}(\mathrm{g})$ & SI mass $(\mathrm{g})$ & SI length $(\mathrm{cm})$ & Pancreas mass $(\mathrm{g})$ \\
\hline HP & 8 & $311.44 \pm 15.04$ & $-10.1 \pm 4.96$ & $6.90 \pm 0.48$ & $64.29 \pm 6.25$ & $0.759 \pm 0.055$ \\
HS & 8 & $293.71 \pm 16.23$ & $-40.07 \pm 18.2$ & $6.81 \pm 0.67$ & $62.72 \pm 6.60$ & $0.634 \pm 0.032$ \\
P-value & & 0.59 & 0.135 & 0.99 & 0.99 & 0.071 \\
\hline
\end{tabular}

*Values are means $\pm \mathrm{SE}(\mathrm{n}=$ number of pigeons $)$
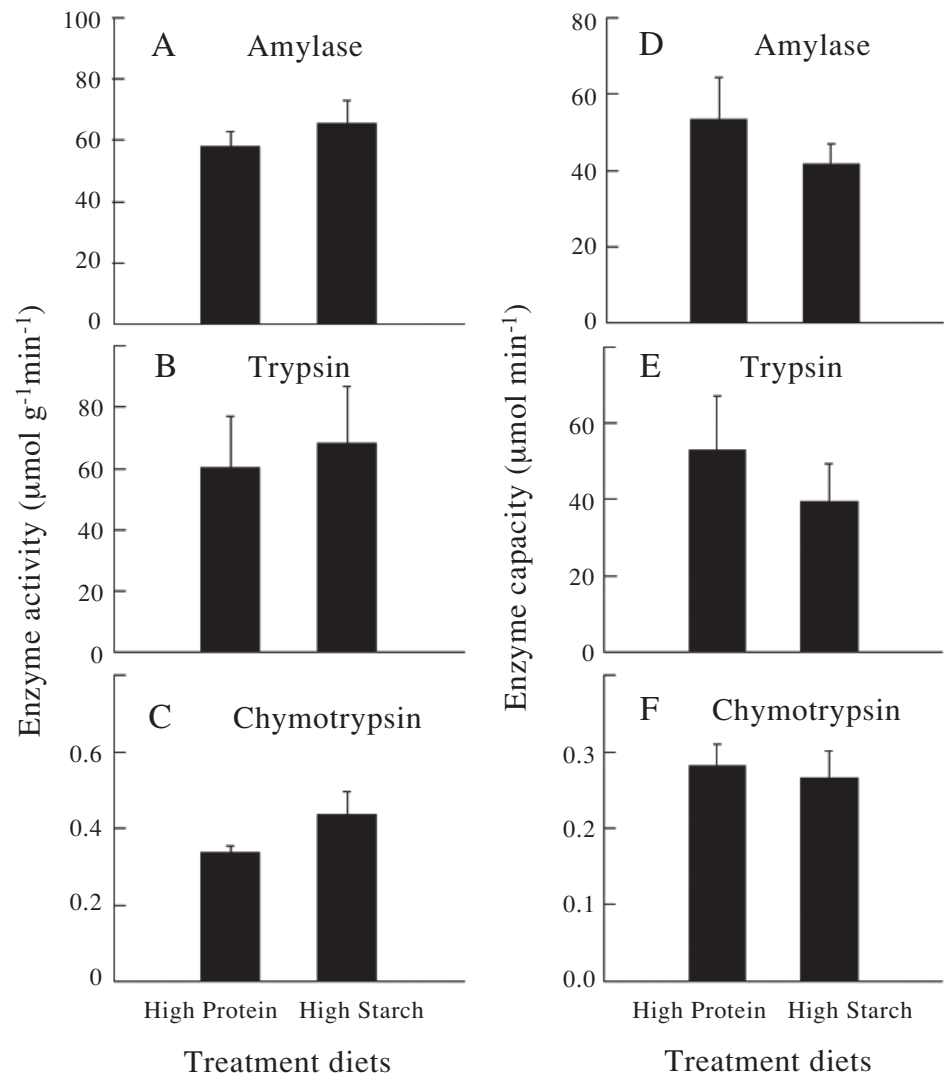

Fig. 1: Activity of specific and summed pancreatic enzymes in feral pigeons fed on two different diets. Bars are means \pm 1 SE. (HP: High protein diet; HS: High starch diet).

Actividad específica y total de las enzimas pancreáticas en palomas domésticas. Las barras representan las medias \pm 1 ES. (HP: Dieta rica en proteínas; HS: Dieta rica en almidón). 
Intestinal activity: specific activity

Effect of diet. Our second prediction was supported; aminopeptidase- $\mathrm{N}$ exhibited a dietary effect in the predicted direction, birds fed on high protein diet had significantly larger activities of this enzyme when compared to birds fed on high starch (Table 2, Fig. 2C). Multiple comparisons Tukey HSD test revealed a dietary effect on the proximal and medial aminopeptidase- $\mathrm{N}$ activities on birds fed on high protein diet $(\mathrm{HP}>\mathrm{HS}, \mathrm{P}<0.05)$, while in the distal portion of the small intestine no difference was observed $(\mathrm{HP}=\mathrm{HS}, \mathrm{P}>0.05)$. Proximal and medial section activities of birds fed on high protein diet were, respectively, 40 and $88 \%$ higher than those of birds fed on high starch diet.

Our third prediction was sustained as well, no diet effect on the carbohydrases activities was apparent (Table 2, Fig. 2A and 2B).

Positional effect. All three enzymes exhibited a significant positional effect (Table 2 ), where the proximal and medial activities were higher than the distal despite the diet (Tukey HSD, $\mathrm{P}<0.05$ ).

Protein content. The small intestine protein content did not differ significantly between diets in any of the intestinal regions (data not shown) and the averaged $0.233 \pm 0.016 \mathrm{~g}$ protein per $g$ of small intestine. Intestinal protein content was significantly correlated with intestinal mass $\left(\mathrm{F}_{1,9}=19.97, \mathrm{P}<0.01\right)$.

\section{Summed activity}

Diet did not affect the summed hydrolysis rates of maltase $\left(\mathrm{F}_{1,14}=0.202, \mathrm{P}=0.659\right)$ and sucrase $\left(\mathrm{F}_{1,14}=1.080, \mathrm{P}=0.316\right)$, nevertheless, pigeons fed on the high protein diet exhibited a higher aminopeptidase- $\mathrm{N}$ summed activity $\left(\mathrm{F}_{1,14}=4.585, \mathrm{P}<0.05\right)$ when compared to birds fed on the HS diet (Fig. 2D, 2E, and 2F).

\section{Relationship between maltase and sucrase}

As a partial test for sucrase-independent maltase-glucoamylase activity (Martínez del Río 1990), we regressed the summed activity of maltase against sucrase. Theoretically, the intercept of this relationship estimates the activity of sucrase-independent maltase (i.e., maltase-glucoamylases; Semenza \& Auricchio
1989) and the slope estimates the contribution of sucrase-isomaltase to maltose hydrolysis. In our birds, intestinal maltase activity was significantly correlated with intestinal sucrase activity $\left(\mathrm{F}_{1,14}=14.665, \mathrm{P}=0.002\right)$. No difference was apparent for the relationship maltase vs. sucrase activity relationships among diets $\left(\mathrm{F}_{1,13}=0.764, \mathrm{P}=0.398\right)$, thus we regressed all data together $\mathrm{y}=243.52( \pm$ $110.52)+10.11( \pm 2.64)$. The intercept was positive and statistically different from zero $(\mathrm{t}$ $=2.202, \mathrm{P}=0.045)$. The contribution of sucrase to maltase activity in the intestine was estimated by multiplying the slope of the maltase vs. sucrase relationship by the summed sucrase activity $\left(39.96 \pm 3.24 \mu \mathrm{mol} \mathrm{min} \mathrm{m}^{-1}\right)$. Sucrase, thus apparently accounted for $62.38 \%$ of the maltase activity $(647.49 \pm 45.83 \mu \mathrm{mol}$ $\mathrm{min}^{-1}$ ). In other words there was evidence for maltase-glucoamylase activity independent of sucrase that accounted for $37.62 \%$ (100-62.38) of all maltase activity.

\section{DISCUSSION}

\section{Acclimation to a diet rich in protein content}

In this study wild captured feral pigeons were habituated for 15 days to synthetic diets that varied in protein and carbohydrate contents. In total agreement with our first prediction, birds fed on a high protein diet were able to survive with no other dietary supplement, maintaining body mass and exhibiting no apparent malnutrition symptoms. Indeed, there was no difference in body mass between both high protein and high starch diet birds (see results). The inclusion by feral pigeons of other food items different from starchy substances (e.g., seeds, grains), like high-protein foods (e.g., arthropods, animal made up pieces), may play an important role in pigeons diet. Thus, pigeons that live in or around cities are opportunistic, exploiting available resources with different chemical composition. This hypothesis may contribute to explain the success of feral pigeons in urban sites. An interesting evolutionary question that emerges from this study that begs for testing is to know if congener species of feral pigeons have the same capacities to exploit food items rich in high protein and survive. 
TABLE 2

Statistics of a repeated measure ANOVA for intestinal enzyme activities under two dietary treatments and intestinal position

Valores estadísticos de un ANOVA de mediciones repetidas de las actividades de enzimas intestinales de dos dietas diferentes, y de distintos segmentos intestinales

\begin{tabular}{|c|c|c|c|c|c|c|c|}
\hline \multirow[t]{3}{*}{ Treatment } & \multirow{3}{*}{$\begin{array}{l}\text { Degrees of } \\
\text { freedom }\end{array}$} & \multicolumn{6}{|c|}{ Enzyme activity } \\
\hline & & \multicolumn{2}{|c|}{ Maltase } & \multicolumn{2}{|c|}{ Sucrase } & \multicolumn{2}{|c|}{ Aminopeptidase-N } \\
\hline & & F-value & P-value & F-value & P-value & F-value & P-value \\
\hline Diet & 1,11 & 1.168 & 0.303 & 1.219 & 0.293 & 9.482 & 0.010 \\
\hline Position & 2,22 & 30.150 & $<0.001$ & 33.274 & $<0.001$ & 9.788 & 0.001 \\
\hline Diet $\mathrm{x}$ position & 4,22 & 3.090 & 0.066 & 3.608 & 0.044 & 2.638 & 0.094 \\
\hline
\end{tabular}
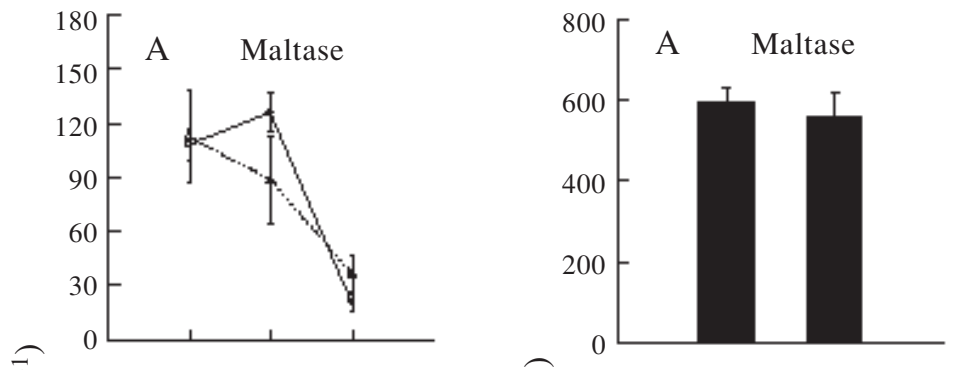

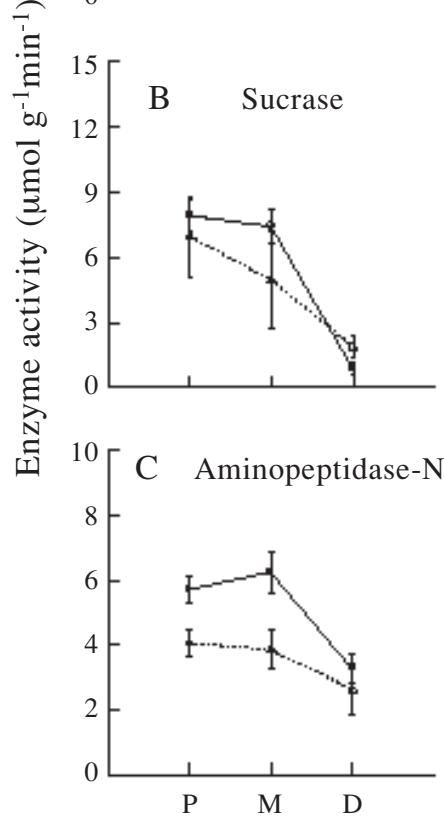

Intestinal section

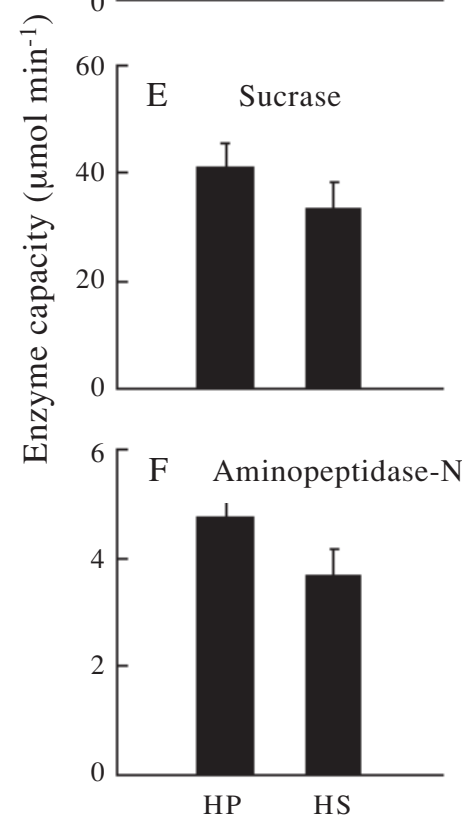

Treatment diets

Fig. 2: Intestinal brush border enzyme activity in feral pigeons fed on two different diets. Values are coded according to the feral pigeon's diet (black solid line and circle, HP: High protein diet; unfilled dashed line and triangles, HS: High starch diet). Statistical comparisons are in Table 2.

Actividad de las enzimas intestinales en palomas domésticas. Los valores están codificados de acuerdo a la dieta de las palomas (línea continua y círculo lleno, HP: Dieta rica en proteínas; línea cortada y triángulos, HS: Dieta rica en almidón). Las comparaciones estadísticas están en la Tabla 2. 


\section{Gut morphometrics}

In our experiments, the small intestine mass and lengths of the pigeons were not affected by high protein treatment when compared to birds fed on the starch diet. Among birds, a nonhomogeneous morphological response of the gut has been found when shifting to a high protein diet. Afik et al. (1995) contrasted yellow-rumped warblers after a seven day acclimation to either a fruit (high carbohydrate) or an insect (high protein) diet. These birds exhibited small intestines with similar length, but different mass (fruit>insect); yet authors caution about a possible methodological imprecision when measuring the mass. In a 20 days-trial, European starlings (Martínez del Río et al. 1995) fed on rich in protein diet had longer small intestines and larger nominal intestinal surface areas but not heavier intestines compared to birds supplied with a high carbohydrate diet. In an opposite direction, Levey et al. (1999) reported that warblers acclimated for 54 days on several composite diets, had heavier but not longer intestines on a high carbohydrate diet (fruits) when compared to birds maintained on a high protein diet (insects). In two different studies on house sparrows fed with the same semisynthetic diets (high protein or high starch) revealed a dissimilar output (CaviedesVidal \& Karasov 1996, Caviedes-Vidal et al. 2000). In the first study, birds were acclimated to the diets for 3 weeks and had different small intestine mass and length (high protein $>$ high starch), while in the second, birds acclimated for ten days did not exhibit any morphometry differences in their intestine. Zonotrichia capensis and Diuca diuca exposed to either a carbohydrate diet or a carbohydrate free diet (protein replaced carbohydrate) for 30 days showed no differences of the intestine mass among diets (Sabat et al. 1998). Examining the available evidence there is not a clear relationship between the size of the intestines and the diet. Why a bird would change the size of the intestines? Adjustments of the sizes have been related to incremented feeding rates, due either to cold, low quality food (high fiber) or reproduction (reviewed by Karasov 1996). Mechanistically, an enlargement may be predicted if reaction rates (hydrolysis or absorption) and their plasticities are not enough to match an increase of the whole digesta or from a specific substrate with no decrease of the digestive efficiency. A shortening of the gut size may be related with the maintenance cost of a structure with excessive unused spare capacity. In our study case, feral pigeons did not seem to need an increase of the gut since they showed adequate fixed carbohydrase enzyme activity and for protein processing they exhibited enough plasticity of the tissuespecific aminopeptidase- $\mathrm{N}$ activity (see below for further discussion of the activities).

As for intestines, pancreas mass was not significantly correlated to diets (pancreas mass did not change, Table 1). The same results were obtained in two passerine species (pine warblers (Levey et al. 1999) acclimated during 54 days and, yellow-rumped warblers (Ciminari et al. 2001) acclimated during 7 days, pancreas mass did not change between diets contrasting in protein content, despite the differences in acclimation periods.

Summarizing, the gut morphometry of feral pigeons is not affected when these birds exploit high protein food items. In other words, the digestive plasticity to process contrasting diet composition does not rely on morphological adjustments of the gut, which is apparent in several other avian species.

\section{Pancreatic enzyme activities}

Very few data of specific (normalized by tissue size) or total pancreatic enzymes activity are yet available preventing us to perform comparisons at the interspecies or interpopulation levels. In this view, it is import to emphasize that feral pigeons have detectable levels of all three pancreatic enzymes. Specific amylase activity per gram pancreas is low compared with other species (Ciminari et al. 2001). Specific chymotrypsin activity is a slightly lower than in yellow-rumped warblers and trypsin is about a twice higher than the activity of yellow-rumped warblers (Ciminari et al. 2001). Summed chymotrypsin and trypsin hydrolysis activities of the whole pancreas in pigeons were also higher than in yellowrumped warblers (Ciminari et al. 2001). Therefore, for one the first relevant steps of enzyme digestion, feral pigeons have an adequate biochemical machinery to afford the digestion of carbohydrates and proteins. 


\section{Intestinal enzymes activity}

Our specific disaccharidase activity values are higher than the values reported for house sparrows, yellow-rumped warblers and pine warblers (Afik et al. 1995, Levey et al. 1999, Caviedes-Vidal et al. 2000) but not for chickens $(156.24 \pm 29.51$ Ciminari et al. unpublished results), where disaccharidases are much higher than in all species cited. Conversely, pigeon's aminopeptidase-N activity reached the levels of house sparrows, yellow-rumped warblers, pine warbler (Afik et al. 1995, Levey et al. 1999, Caviedes-Vidal et al. 2000), but not the hydrolysis rate of chickens which is more than double of the level of pigeons (10.31 \pm 0.95 Ciminari et al. unpublished results).

\section{Effect of intestinal position on activity}

Feral pigeons display an unusual spatial pattern of aminopeptidase- $\mathrm{N}$ activity. The expression of the enzyme remains unchanged along the small intestine in birds fed on the high starch diet, but for those on high protein diet, the activity was significantly higher in the medial portion. This is coincident with the finding that proline uptake is higher in the medial portion, than in the proximal and distal portions, in pigeons (Obst and Diamond 1989). Other patterns found among bird species include a high aminopeptidase- $\mathrm{N}$ activity in the distal section compared to the proximal and medial section of the intestine, such the case of house sparrows (Caviedes-Vidal et al. 2000), coastal Cinclodes (Sabat \& González 2003) and Canada geese (Ciminari 1997), while for pine warblers (Levey et al. 1999), yellow-rumped warblers (Afik et al. 1995) and European starlings (Martinez del Río et al. 1995) the protein breakdown membrane-bound related activity remains unchanged or decreases along the proximal to the medial and distal portions.

Disaccharidase activities along the small intestine of feral pigeons, followed a general pattern demonstrated in most of the birds studied up to now, a pronounced decline towards the distal region (Afik et al. 1995, Ciminari et al. $1998^{4}$, Levey et al. 1999, Caviedes-Vidal et al. 2000, Sabat \& González 2003).

\footnotetext{
4 CIMINARI ME, E CAVIEDES-VIDAL, S MC WILLIAMS \& WH KARASOV (1998) Dietary modulation of the intestinal disaccharidases maltase and sucrase in the Canada geese (Branta canadensis). Biocell 22: 16.
}

Pattern and magnitude of dietary modulation of pancreatic and intestinal enzymes

In our study any pancreatic enzyme activity changed following an increase in their respective substrate. Among species, there is a considerable variation of the modulation of pancreatic enzymes as a response for a dietary switch. Different results have been observed within omnivorous wild birds. House sparrows (Caviedes-Vidal \& Kasarov. 19955) and yellowrumped warblers (Ciminari et al. 2001) did not modulate any of the enzymes, while pine warbler (Levey et al. 1999) modulated amylase, trypsin and chymotrypsin. On the other hand, in the chicken, the levels of amylase and proteases change in proportion to dietary content of their respective substrates (Imondi \& Bird 1967, Hulan \& Bird 1972). The number of species reported is small, so is premature to suggest a dietary modulation pattern of pancreatic enzymes in birds. However, is noticeable that feral pigeons show the same pattern as most passerines species dietary modulation of their pancreatic enzymes activity. Two of the three pancreatic enzymes, amylase and trypsin, have elevated constitutive levels, thus we may state that pigeons have the required (and more) biochemical machine to break down the carbohydrates that reach the digestive tract.

Intestinal enzyme results supported the direction of our predictions and conform a pattern for all passerine species studied up to date, with the solely exception of pine warbler. Modulation of the hydrolytic and transport activity of the intestine's brush border may involve changes in absorption and hydrolysis rates due to altered densities of transporters and hydrolases per unit intestinal mass/area ("specific modulation") or, may involve changes in intestinal mass and/or area ("non-specific modulation", Karasov \& Diamond 1983). We only found specific modulation in one of the intestinal enzyme activity studied, aminopeptidase-N; this enzyme reached higher levels in birds fed on the high protein diet vs. those fed low protein diet (high starch diet), although the increment was restricted to the medial portion. Disaccharidases did not show

\footnotetext{
5 CAVIEDES-VIDAL E \& WH KARASOV (1996) Influences of diet composition on pancreatic enzyme activities in house sparrows. American Zoologist 35: 78A.
} 
significant differential levels between birds fed on the two diets. As for non-specific modulation, we did not find it in our study, an obvious consequence when no changes of the intestinal mass and/or length undergo along with the diet treatments.

\section{Ecological and evolutionary implications of dietary modulation}

As for intestinal enzymes, feral pigeons followed the pattern observed for Passeriformes and for birds having vestigial and non-functional caeca. Thus, on one hand, our results give apparent support to the functional hypothesis (Caviedes-Vidal et al. 2000), which states that a small intestinal escape of amino nitrogen as peptides to the cecum can support microbial growth, contrary to the small intestine of the passerines, which may have been selected to extract the maximum available amino nitrogen, rather than excreting it as waste. Additionally, these different ways to extract nitrogen from the diet may reveal differences in the ecological behaviour of the animals, principally concerning to the food choices that they make, in a particular habitat. Recent studies in chickens and quails (Ciminari et. al unpublished results) and in geese (Ciminari 1997), gives support to this idea too. On the other hand, our findings are not enough to reject that the observed intestinal protease dietary modulation has a phylogenetic component because feral pigeons are closely related to Passeriformes, in fact they belong to the parvclass Passerae. Summarizing, the data presented here increase our knowledge and help clarifying the scenario for to have a definitive answer, which would require testing Passerae species having a functional caeca and Galloanserae species lacking cecum.

\section{Pigeons living on a high protein diet}

In short, this is the first study that establishes a relationship between the energy acquisition from food in pigeons that live in urban environments and thriving in them. Feral pigeons have the ability to take full advantage of the energy content from proteins, having enough pancreatic proteases activity and modulating the intestinal aminopeptidase-N. These abilities may allow them to use effectively the nutrients found in the cities, especially when environmental availability of starchy foods are scarce.

\section{ACKNOWLEDGMENTS}

This study is dedicated to the memory of our beloved Prof. Mario Rosenmann, as a modest recognition of all the academic and human knowledge we received from him. We thank Carlos Codorniú for his logistic support in the laboratory. MEC and JGC are UNSL and CONICET fellowship holders respectively. The work was supported by CyT-UNSL 22Q151 and FONCYT PICT98 01-3101 grants to EC-V.

\section{LITERATURE CITED}

AFIK D, E CAVIEDES-VIDAL, C MARTÍNEZ DEL RÍO \& WH KARASOV (1995) Dietary modulation of intestinal hydrolytic enzymes in yellow-rumped warblers. American Journal of Physiology 269: R413-R420.

BELL GP (1990) Birds and mammals on an insect diet: a primer on composition analysis in relation to ecological energetics. In: Morrison ML, CJ Ralph, J Verner \& RR Jehl (eds) Avian foraging: theory, methodology and applications: 416-422. Studies in Avian Biology 13, Cooper Ornithological Society and Allen Press, Lawrence, Kansas, USA.

BIVIANO AB, C MARTÍNEZ DEL RÍO \& DL PHILLIPS (1993) Ontogenesis of intestine morphology and intestinal disaccharidases in chickens (Gallus gallus) fed contrasting purified diets.Journal of Comparative Physiology B 163: 508-518.

BRANNON PM (1990) Adaptation of the exocrine pancreas to diet. Annual Review of Nutrition 10: 85-105.

CAVIEDES-VIDAL E \& WH KARASOV (1996) Glucose and amino acid absorption in house sparrow intestine and its dietary modulation. American Journal of Physiology 271:R561-R568.

CAVIEDES-VIDAL E, D AFIK, C MARTÍNEZ DEL RÍO \& WH KARASOV (2000) Dietary modulation of intestinal enzymes of the house sparrow (Passer domesticus): testing an adaptive hypothesis. Comparative Biochemistry and Physiology, Part A 125: $11-24$

CIMINARI ME (1997) Actividad de las enzimas intestinales y del ciego en gansos del Canadá (Branta canadensis) de América del Norte. Tesis de Magíster, Universidad Nacional de San Luis, San Luis, Argentina. 73 pp.

CIMINARI ME, D AFIK, WH KARASOV \& E CAVIEDES-VIDAL (2001) Is diet-shifting facilitated by modulation of pancreatic enzymes? Test of an adaptational hypothesis in yellowrumped warblers. Auk 118: 1101-1108.

DAHLQVIST A (1962) A method for the determination of amylase. Scandinavian Journal of Clinical Investigation 14: 145-157.

DAHLQVIST A (1984) Assay of intestinal disaccharidases. Scandinavian Journal of Clinical Investigation 44: 69-172. 
ERLANGER BF, N KOKOVSKY \& W COHEN (1961) Preparation and properties of two new chromogenic substrates of trypsin. Archives of Biochemistry and Biophysics 95: 271-278.

ERLANGER BF, F ADEL \& GA COOPER (1966) Action of chymotrypsin on two new chromogenic substrates. Archives of Biochemistry and Biophysics 115: 206-210.

GARLAND T JR (1992) Rate tests for phenotypic evolution using phylogenetically independent contrasts. American Naturalist 140: 509-519.

GRAY GM (1992) Starch digestion and absoption in nonruminants. Journal of Nutrition 122: 172-177.

HARVEY P H \& M D PAGEL (1991) The comparative method in evolutionary biology. Oxford University Press, Oxford, United Kingdom. 239 pp.

HULAN HW \& FH BIRD (1972) Effect of fat level in isonitrogenous diets on the composition of avian pancreatic juice. Journal of Nutrition 102: 459-468.

HUNZIKER W, M SPIESS, G SEMENZA \& HF LODISH (1986) The sucrase-isomaltase complex: primary structure, membrane orientation, and evolution of a stalked, intrinsic brush border protein. Cell 46: 227-34.

IMONDI AR \& FH BIRD (1967) Effects of dietary protein level on growth and proteolytic activity of the avian pancreas. Journal of Nutrition 91: 421-428.

JOHNSTON R F \& M JANIGA (1995) Feral pigeons. Oxford University Press, New York, New York, USA. 319 pp.

JOKIMAKI J \& J SUHONEN (1998) Distribution and habitat selection of wintering birds in urban environments. Landscape and Urban Planning 39: 253-263.

KARASOV WH (1996) Digestive plasticity in avian energetics and feeding ecology. In: Carey C (ed) Avian energetics and nutritional ecology: 61-84. Chapman and Hall, New York, New York, USA

KARASOV WH \& JM DIAMMOND (1983) Adaptive regulation of sugar and amino acid transport by vertebrate intestine. American Journal of Physiology 245: G443-G462.

KARASOV WH \& ID HUME (1997) Vertebrate gastrointestinal system. In: Dantzler W \& MD Bethesda (eds) Handbook of Comparative Physiology: 409-480. American Physiological Society and Oxford University Press, Oxford, United Kingdom.

LEFEBVRE L \& LA GIRALDEAU (1984) Daily feeding site use of urban pigeons. Canadian Journal of Zoology 62: 1425-1428.

LEVEY DJ, A PLACE, P REY \& C MARTÍNEZ DEL RÍO (1999) An experimental test of dietary enzyme modulation in pine warblers (Dendroica pinus). Physiological and Biochemical Zoology 72: 576-587.

MAROUX S, D LOUVARD \& J BARATTI (1973) The aminopeptidases from hog intestinal brush-border. Biochimica and Biophysica Acta 321: 282-295.

MARTÍNEZ DEL RÍO C (1990) Dietary, phylogenetic, and ecological correlates of intestinal sucrase and maltase activity in birds. Physiological Zoology 63: 987-1011

MARTÍNEZ DEL RÍO C, KE BRUGGER, JL RÍOS, ME VERGARA \& M WITMER (1995) An experimental and comparative study of dietary modulation of intestinal enzymes in an omnivorous passerine bird: the European Starling (Sturnus vulgaris). Physiological Zoology 68: 490-511.

MCLELLAND J (1989) Anatomy of the avian cecum. Journal of Experimental Zoology, Supplement 3: 2-9.

NOREN O, H SJOSTROM, EM DANIELSEN, GM COWELL \& H SKOVBJERG (1986) The enzyme of the enterocyte plasma membrane. In: Desnuelle $\mathrm{P}, \mathrm{H}$ Sjostrom \& $\mathrm{O}$ Noren (eds) Molecular and cellular basis of digestion: 335-365. Elsevier Science Publishers, New York, New York, USA.

OBST BS \& JM DIAMMOND (1989) Interespecific variation in sugar and amino acid transport by the avian cecum. Journal of Experimental Zoology, Supplement 3: 117-126.

RAUL F, T GODA, F GOSSÉ \& O KOLDOVSKY (1987) Short-term effect of a high-protein/lowcarbohydrate diet on aminopeptidase in adult rat jejunoileum. Biochemistry Journal 247: 401-405.

SABAT P, F NOVOA, F BOZINOVIC \& C MARTÍNEZ DEL RÍO (1998) Dietary flexibility and intestinal plasticity in birds: a field and laboratory study. Physiological Zoology 71: 226-236.

SABAT P \& S GONZÁLEZ (2003) Digestive enzymes in two species of marine Cinclodes (Passeriformes: Furnariidae). Condor 105: 830-833.

SELL JL, O KOLDOVSKY \& BL REID (1989) Intestinal disaccharidases of young turkeys: temporal development and influence of diet composition. Poultry Science 68: 265-277.

SEMENZA G \& S AURICCHIO (1989) Small Intestine Disaccharidases. In: Scribner CR, AL Beaudet, WS Sly \& D Valle (eds) The metabolic basis of inherited disease (II): 2975-2997. Mc Graw-Hill, New York, New York, USA.

SIBLEY C \& J AHLQUIST (1990) Phylogeny and classification of birds: a study in molecular evolution. Yale University Press, New Haven, Connecticut, USA. $1080 \mathrm{pp}$

SIBLY RM (1981) Strategies of digestion and defecation. In: Townsend CR \& P Calow (eds) Physiological ecology: an evolutionary approach to resource use: 109-139. Blackwell Scientific Publications, Oxford, United Kingdom.

SIDDONS RC (1972) Effect of diet on disaccharidase activity in the chick. British Journal of Nutrition 27: $343-352$.

SOL D, D SANTO, J GARCÍA \& M CUADRADO (1998) Competition for food in urban pigeons: the cost of being juvenile. Condor 100: 298-304.

VONK HJ \& RH WESTERN (1984) Comparative biochemistry and physiology of enzymatic digestion. Academic Press, London, United Kingdom. 501 pp.

WILKINSON L (1992) Systat for Windows-Statistics, 5. Systat, Evanston, Illinois, USA. 